\title{
Inhibitory Effects of oxalic acid on Listeria monocytogenes, Salmonella Enteritidis and Escherichia coli O157:H7 inoculated onto Chicken Breast stored at $4^{\circ} \mathrm{C}$
}

\author{
D. M. Anang ${ }^{1 *}$, G. Rusul ${ }^{2}$, H. M. Moda ${ }^{1}$
}

${ }^{1}$ Food, Nutrition and Health Research Centre, Manchester Metropolitan University, Manchester, M15 6BG United Kingdom.

${ }^{2}$ School of Industrial Technology, Universiti Sains Malaysia, USM, Penang, Malaysia.

\section{Abstract}

Oxalic acid was evaluated for its effectiveness in inhibiting growth of selected pathogens on raw chicken breasts. Inoculated chicken breasts were dipped in oxalic acid solutions $(0,0.5,1.0,1.5$ and $2.0 \% \mathrm{w} / \mathrm{v})$ for 10,20 , and $30 \mathrm{~min}$, packed in oxygenpermeable polyethylene bags, and stored at $4^{\circ} \mathrm{C}$. Oxalic acid residues were determined using HPLC method. Counts of pathogens on chicken breasts were determined on days $0,2,5,7,10$, and 14 after storage. Maximum oxalic acid concentration in unwashed chicken breast was $36 \mathrm{mg} / 100 \mathrm{~g}$. Washing of chicken reduced oxalic acid concentration by $50 \%$. Oxalic acid concentration in cooked breast was $2 \mathrm{mg} / 100 \mathrm{~g}$ which is quite lower than levels in vegetables and herbs, used in daily diets. Chicken meat treated with oxalic acid could therefore be safe for human consumption. Reduction by 2.87, 2.02 and $4.12 \log \mathrm{CFU} / \mathrm{g}$, of L. monocytogenes, $S$. Enteritidis and E. coli O157:H7 respectively was observed in treated samples. Counts of the pathogens in treated samples decreased compared to untreated samples during 14 days storage. Sensory evaluation of cooked oxalic acid treated samples was acceptable to consumers after 14 days of storage. It was evident that oxalic acid has great potential for decontamination of chicken carcasses.

Keywords: Decontamination; Oxalic acid; Poultry; Listeria monocytogenes, Salmonella Enteritidis; Escherichia coli O157:H7.

\section{*Corresponding Author:}

D. M. Anang,

Food, Nutrition and Health Research Centre, Manchester Metropolitan University, Manchester, M15 6BG United Kingdom.

Tel: +44 (0) 1612476461

E-mail: d.m.anang@mmu.ac.uk

Received: September 07, 2015

Accepted: November 11, 2015

Published: November 19, 2015

Citation: D. M. Anang, G. Rusul, H. M. Moda (2015) Inhibitory Effects of Oxalic Acid on Listeria Monocytogenes, Salmonella Enteritidis and Escherichia coli $\mathrm{O} 157: \mathrm{H} 7$ inoculated onto Chicken Breast stored at $4^{\circ} \mathrm{C}$. Int J Food Sci Nutr Diet. 04(6), 233-238. doi: http://dx.doi.org/10.19070/23263350-1500042

Copyright: D. M. Anang ${ }^{\circ}$ 2015. This is an open-access article distributed under the terms of the Creative Commons Attribution License, which permits unrestricted use, distribution and reproduction in any medium, provided the original author and source are credited.

\section{Introduction}

Poultry meat is one of the most common foods that cause foodborne infection and intoxication in humans [1]. Epidemiological reports available have implicated poultry as a major source for human food poisoning outbreaks $[2,3]$. Poultry slaughtered in modern poultry processing plants is reported to harbour as many as 27 different species of bacteria [1], some of which are known to be pathogenic to humans. These pathogens are present on feathers and skin of broilers which can enter into the processing plant [4]. In poultry, foodborne disease is caused by pathogens such as Salmonella, Campylobacter jejuni and Listeria monocytogenes which are of great concern globally $[3,5,6]$. Other frequently encountered pathogens such as E. coli O157:H7 and Staphylococcus aureus are also of great concern to the food industry as they are identified as high risk pathogens in temperature abused, ready-to-eat (RTE) pork and poultry-meat products with extended shelf life [7, 8].

Of late, researchers have developed numerous decontamination strategies such as the use of chemicals, organic acids, hot water rinsing and irradiation to reduce the number of pathogenic bacteria capable of causing human diseases via poultry. The use of chemicals and organic acids in reducing pathogens in poultry have proven to be beneficial [9-11].

Oxalic acid, a final metabolic product of plants, including radish, spinach, parsley, carrots etc., has been recognised to possess various functions such anti-browning, antioxidant, intrinsic heat tolerance and inhibition of peroxidase and polyphenol oxidase activities [12-14]. In addition, Huang et al. [12] observed that oxalic acid can effectively control pericarp browning of litchi and banana during postharvest storage. Previously, Anang et al. [15] reported the inhibitory effect of oxalic acid on spoilage microorganisms, including Pseudomonas spp. and those of the Enterobacteriaceae family, in raw chicken. Their results showed that oxalic acid was effective in reducing populations of major spoilage microorganisms on raw chilled chicken breast.

The objective of the present study was to evaluate the effectiveness of oxalic acid in inhibiting growth of Salmonella Enteritidis, E. coli $\mathrm{O} 157: \mathrm{H} 7$ and L. monocytogenes inoculated onto raw chicken breast. It is envisaged that the results obtained from the present study will provide further information on the effectiveness of oxalic acid as a decontamination product for raw poultry and its 


\section{resultant benefit to consumers.}

\section{Materials and Methods}

\section{Preparation of bacterial inoculum}

Cultures of Listeria monocytogenes (L55), Salmonella Enteritidis (S552) and Escherichia coli O157:H7 (E19 - characterised as a non-sorbitol fermenting), originally isolated from patients with foodborne illness, were obtained from the Malaysian Institute for Medical Research. The cultures were activated by transferring $0.05 \mathrm{ml}$ of a frozen $\left(-20^{\circ} \mathrm{C}\right)$ stock culture into $10 \mathrm{ml}$ Tryptone Soy Broth (TSB) (Merck, Darmstadt, Germany) and incubated overnight at $35^{\circ} \mathrm{C}$. This was then streaked onto Tryptone Soy Agar (TSA) (Merck, Darmstadt, Germany) and incubated for $24 \mathrm{~h}$ at $35^{\circ} \mathrm{C}$. Working cultures were kept on TSA slants at $8^{\circ} \mathrm{C}$ and sub-cultured every 2 weeks. Bacterial inoculum was prepared according to the method described by Anang et al. [16] by transferring culture from the slants to $10 \mathrm{ml}$ TSB and incubated at $35^{\circ} \mathrm{C}$ for $24 \mathrm{~h}$. The $10 \mathrm{ml}$ culture was later transferred to $990 \mathrm{ml}$ TSB and incubated for 18 h. The inoculum was subsequently diluted with fresh TSB on the day of inoculation to yield c.a. $10^{8}-10^{9} \mathrm{CFU} / \mathrm{ml}$ of $\mathrm{L}$. monocytogenes (L55), S. Enteritidis (S552) and E. coli 0157:H7 (E19).

\section{Inoculation of chicken breast}

Fresh, raw chicken breasts (approximately $150 \mathrm{~g}$ each) were procured immediately after slaughter. The samples were placed on ice and transferred to the laboratory within $20 \mathrm{~min}$ and stored at $4^{\circ} \mathrm{C}$ for no longer than 2 hours before being used. Each chicken breast was decontaminated, according to the method described by Anang et al. [16] and Greer and Dilts [17], by dipping in 70\% ethanol, passed through a flame of a Bunsen burner and allowed to cool. The decontaminated chicken breasts were dipped in suspension of L. monocytogenes, S. Enteritidis or E. coli O157:H7 (10 $\left.{ }^{9} \mathrm{CFU} / \mathrm{ml}\right)$ at room temperature $\left(25^{\circ} \mathrm{C}\right)$ for $15 \mathrm{~min}$. Ratio of chicken breast to culture suspension was 1:2 (w/v), which allowed complete immersion of the chicken breast. Initial counts of L. monocytogenes, S. Enteritidis and E. coli $\mathrm{O} 157: \mathrm{H} 7$ in chicken breast immediately after dipping in the inoculum suspension ranged from log 6.8- $\log$ 7.5 CFU/g. Thereafter, the chicken breasts were kept at room temperature for $20 \mathrm{~min}$ to allow for inoculum attachment. Inoculated chicken breast $\left(150 \mathrm{~g}\right.$ and $\left.25^{\circ} \mathrm{C}\right)$ was subsequently dipped in $200 \mathrm{ml}$ of 0 (control - sterile distilled water), $0.5,1,1.5$ or $2 \%$ of oxalic acid (w/v) for 10, 20 or $30 \mathrm{~min}$ [15]. Chicken were completely immersed in the treatment solutions without stirring or agitation. After the oxalic acid dipping, the chicken breast samples were placed in a sterile plastic colander to drain the excess water (control) or oxalic acid solution, and individually placed in Low Density Polyethylene (LDPE) bags (oxygen transmission rate $2600 \mathrm{~cm}^{3} / \mathrm{m}^{2} /$ atm for $1 \mathrm{ml}$ film at $25^{\circ} \mathrm{C}$ ). Chicken breasts were subjected to microbial analysis after treatment (day 0 ) and storage for $2,5,7,10$ and 14 days at $4^{\circ} \mathrm{C}$. The experiment was repeated twice. In each experiment, two chicken breasts from each treatment were analysed at each sampling time.

\section{Microbiological sampling and analysis}

A $25 \mathrm{~g}$ sample of breast muscle was excised using a sterile knife and transferred into a stomacher bag containing $225 \mathrm{ml}$ of $0.1 \%$ sterile Buffered Peptone water (Oxoid CM509) and homogenized using Lab-blender 400 (Seward Laboratory, London) stomacher for $45 \mathrm{~s}$. Serial dilutions were prepared using $0.1 \%$ sterile buffered peptone water and inoculated onto duplicate agar plates using a
Whitely Automatic Spiral Plater (WASP2 - Don Whitely Scientific Ltd., Shipley, West Yorkshire, U.K.). One hundred microlitre $(100 \mu \mathrm{l})$ of respective dilutions were inoculated onto agar plates. Listeria monocytogenes was enumerated on PALCAM Listeria selective agar base (PALCAM, Merck 1.12122.0001, Darmstadt, Germany) according to Van Netten, et al. [18], to which PALCAM Listeria selective supplement (PALCAM, Merck 1.11755, Darmstadt, Germany) was added. The plates were incubated at $35^{\circ} \mathrm{C}$ for $48 \mathrm{~h}$ before counting. Salmonella counts were determined by plating diluted samples on XLT4 agar base (Merck 1.13919) supplemented with Sodium tetradecyl sulfate solution (XLT4 agar supplement, Merck 1.08981.0100) and incubated at $37^{\circ} \mathrm{C}$ for 24 h. Enumeration of E. coli O157:H7 was carried out on Sorbitol MacConkey Agar (CT-SMAC) with 5-bromo-4-chloro-3-indolyl$\beta$-D-glucuronide (BCIG) (Oxoid CM0981) supplemented with Cefixime Tellurite (Oxoid SR0172) and incubated at $37^{\circ} \mathrm{C}$ for 24h. The Whitely Acolyte Automated Colony Counter (Synbiosis Beacon House, Cambridge, UK) was used for counting colonies on each plate.

\section{Determination of oxalic acid residue in treated chicken breast}

Oxalic acid residues in treated chicken breasts were determined using a modified method described by Savage et al. [19]. After dipping in various concentrations of oxalic acid and draining excess solution for $5 \mathrm{~min}$, the samples were divided into 2 groups. One group of samples was washed in distilled water for $2 \mathrm{~min}$ with mild rubbing before extraction while the other group remained unwashed.

Oxalic acid residue was also determined for oven roasted $\left(160^{\circ} \mathrm{C}\right.$ for $30 \mathrm{~min}$ ) chicken breast dipped in 0.5 and $1.5 \%$ oxalic acid for 10 min. Representative samples of chicken breast meat were dried to constant weight at $105^{\circ} \mathrm{C}$ for $24 \mathrm{~h}$ to determine dry matter for calculating the oxalic acid content per $100 \mathrm{~g}$ of fresh weight.

Extraction of oxalic acid: After dipping in the various solutions of oxalic acid, chicken breast were allowed to drain off excess solution and then divided into 2 groups. One group of chicken breast was washed in distilled water before extraction while the other group was not washed. Oxalic acid residue was also determined for oven roast $\left(160^{\circ} \mathrm{C}\right.$ for $\left.30 \mathrm{~min}\right)$ chicken breast that was dipped in 0.5 and $1.5 \%$ oxalic acid for $10 \mathrm{~min}$.

One hundred grams $(100 \mathrm{~g})$ of oxalic acid treated chicken breast (taken from the surface, $3 \mathrm{~mm}$ thick) was cut in smaller pieces, freeze dried for $24 \mathrm{hrs}$, using the Labconco Freezone 1 litre benchtop freeze dry system (Labconco, Missouri, USA) and ground to fine sample size using ceramic piston and mortar. One gram $(1 \mathrm{~g})$ of the ground freeze-dried oxalic acid treated chicken breasts were weighed into $250 \mathrm{~mL}$ beakers and $50 \mathrm{ml}$ of $2 \mathrm{M} \mathrm{HCL}$ added. Each beaker was placed in a water bath at $80^{\circ} \mathrm{C}$ for 15 min. The extract was allowed to cool to room temperature, and then transferred quantitatively into a $100 \mathrm{ml}$ volumetric flasks and made up to $100 \mathrm{ml}$ volume with $2 \mathrm{M} \mathrm{HCl}$. The extracts were later centrifuge at $3000 \mathrm{rpm}$ for $2 \mathrm{~min}$ and $10 \mathrm{ml}$ of the supernatant filtered through a $0.45 \mu \mathrm{m}$ cellulose acetate membrane (Sartorius AG, Goettingen, Germany). A $10 \mu$ l of extract was analysed using a Shimadzu Chromatographic System (Shimadzu Corporation, Japan), consisting of Shimadzu LC-6A Isocratic/Gradient Pump, Shimadzu SPD-6A UV/VIS Spectrophotometric detector set at $214 \mathrm{~nm}$. Chromatographic separation was performed using an 
Aminex HPX-87H 300 x $7.8 \mathrm{~mm}$ organic acid analysis column (Bio-Rad Laboratories, Ca., USA) with isocratic elution set at 0.6 $\mathrm{ml} / \mathrm{min}$ with $0.008 \mathrm{M}$ sulphuric acid as mobile phase. Before use, the mobile phase was filtered through $0.45 \mu \mathrm{m}$ membrane and degassed using a vacuum. A known standard was prepared in the range of 1 to $70 \mathrm{mg} / 100 \mathrm{ml}$ by dissolving oxalic acid in $50 \mathrm{ml}$ 2M HCl. The solution was quantitatively transferred to $100 \mathrm{ml}$ volumetric flasks and made up to $100 \mathrm{ml}$ volume using $2 \mathrm{M} \mathrm{HCl}$. All the standard solutions were filtered through $0.45 \mu \mathrm{m}$ cellulose acetate membrane filter prior to analysis. Each HPLC analysis of the standards and samples were performed in triplicate.

\section{Statistical Analysis}

Statistical analysis of the data obtained was analysed using the SAS software (version 9.4) (SAS Institute Inc., Cary, N.C.). Analysis of variance was carried out at $95 \%$ significance level $(P<0.05)$ and Duncan's $t$ test was used for the means.

\section{Results and Discussion}

\section{Oxalic acid residue in treated chicken breast}

Oxalic acid residues in chicken breast dipped in $0.5-2.0 \%$ oxalic acid solutions for 10, 20 or $30 \mathrm{~min}$ are shown in Table 1 . The highest residual amount of $35.6 \mathrm{mg} / 100 \mathrm{~g}$ was observed when the chicken breast was dipped in $2.0 \%$ oxalic acid for $30 \mathrm{~min}$. This amount which is equivalent to $0.04 \%$ (based on $85 \%$ dry matter of chicken breast) is quite low compared to the reported values in vegetables and herbs used in daily diets including parsley $(1.70 \%$, dry weight basis), chives $(1.48 \%)$, spinach $(0.97 \%)$, beet leaves $(0.61 \%)$, carrots $(0.50 \%)$, and radish $(0.48 \%)$ [20]. Washing of chicken with water significantly reduced oxalic acid residues by $50 \%$ or more (Table 1$)$. In the cooked chicken breast $\left(160^{\circ} \mathrm{C}\right.$ for $30 \mathrm{~min}$.) treated with $0.5 \%$ and $1.5 \%$ oxalic acid, the oxalic acid residues were found to be $1.94 \mathrm{mg} / 100 \mathrm{~g}$ and $2.0 \mathrm{mg} / 100 \mathrm{~g}$, respectively.

Based on the predicted $\mathrm{LD}_{50}$ in rats (of $375 \mathrm{mg} / \mathrm{kg}$ ) [21] and extrapolating from this dose for a person weighing $150 \mathrm{lb}(68.1$ $\mathrm{kg}$ ), consumption of $25.5 \mathrm{~g}$ of oxalic acid is required for an $\mathrm{LD}_{50}$. Based on the rat model considered, it was concluded, an individual would have to consume about $71.63 \mathrm{~kg}$ of the $2.0 \%$ oxalic acid treated chicken breast (unwashed after treatment) to have $25.5 \mathrm{~g}$ oxalic acid required for an $\mathrm{LD}_{50}$. Hence, treating chicken breast with oxalic acid at the current level proposed in the study, and compared to oxalic acid contents in vegetables and herbs used in daily diets, it was concluded that the available amounts contain in the chicken breast after treatment would be safe for human consumption.

\section{Listeria monocytogenes, Salmonella Enteritidis and Escher- ichia coli $0157: \mathrm{H} 7$ growth during storage of chicken breast}

Table 2 shows the log-reduction in L. monocytogenes, $S$. Enteritidis and E. coli $\mathrm{O} 157: \mathrm{H} 7$ inoculated onto chicken breast and treated with different concentrations of oxalic acid. Accordingly, based on the results obtained, the highest reduction was observed in $E$. coli O157:H7 (log 4.12 CFU/g). However, as indicated by Blackburn and McCarthy [22], the use of SMAC-based media may lead to overestimated count of E. coli O157:H7. Report from the work by Clavero and Beuchat [23], Sage and Ingham [24] and Singh et al. [25] have indicated poor recovery of injured cells and therefore underestimation of numbers of viable E. coli $\mathrm{O} 157: \mathrm{H} 7$ when SMAC was used. In addition, previous studies conducted using the methods described by Blackburn and McCarthy [22] observed no difference in injured E. coli O157:H7 cells during organic acid decontamination [26, 27]. The result for Salmonella Enteritidis reduction was less when compared to $L$. monocytogenes which has maximum reductions of $\log 2.02 \mathrm{CFU} / \mathrm{g}$ at the highest concentration after dipping in oxalic acid.

Table 3 presents the result of L. monocytogenes counts in inoculated chicken breast treated with oxalic acid during storage at $4^{\circ} \mathrm{C}$. A decrease in Listeria monocytogenes was recorded until day 2 for samples treated with 0.5 and $1.0 \%$ oxalic acid solutions for 10 , 20 or $30 \mathrm{~min}$. However, Listeria counts on chicken breast dipped in $0.5,1.0$ or $1.5 \%$ oxalic acid solution for 10,20 or 30 min were ca. 1.79-3.24 log CFU/g less on day 2 compared to those before treatment. Listeria counts on chicken breast treated with water (control) decreased slightly on day 2 of storage but increased relatively fast throughout the storage time. There was a significant reduction in Listeria monocytogenes counts when chicken breasts were treated with $2 \%$ oxalic acid for 10 min compared with 20 or 30 min until day 7 of storage. However, a significant decrease in Listeria monocytogenes was observed between the 3 dipping times after

Table 1. Oxalic acid residues $(\mathrm{mg} / 100 \mathrm{~g})$ in chicken breast treated with different concentrations of oxalic acid.

\begin{tabular}{|c|c|c|c|}
\hline \multirow{2}{*}{$\begin{array}{c}\text { Oxalic acid } \\
\text { concentration (\%) }\end{array}$} & $\begin{array}{c}\text { Dipping duration } \\
\text { ( } \mathbf{m i n})\end{array}$ & \multicolumn{2}{|c|}{ Oxalic acid residue in chicken (mg/100g) } \\
\cline { 2 - 4 } & 10 & Unwashed chicken & Washed chicken \\
\hline 0.5 & 20 & $8.97^{\mathrm{a}}$ & $3.84^{\mathrm{b}}(1.94)^{*}$ \\
& 30 & $9.76^{\mathrm{a}}$ & $5.08^{\mathrm{b}}$ \\
& 10 & $11.29^{\mathrm{a}}$ & $5.88^{\mathrm{b}}$ \\
\hline 1.0 & 20 & $10.07^{\mathrm{a}}$ & $4.25^{\mathrm{b}}$ \\
& 30 & $11.29^{\mathrm{a}}$ & $5.06^{\mathrm{b}}$ \\
& 10 & $12.46^{\mathrm{a}}$ & $6.76^{\mathrm{b}}$ \\
\hline 1.5 & 20 & $13.50^{\mathrm{a}}$ & $7.33^{\mathrm{b}}(2.00)^{*}$ \\
& 30 & $20.72^{\mathrm{a}}$ & $10.07^{\mathrm{b}}$ \\
& 10 & $28.66^{\mathrm{a}}$ & $14.88^{\mathrm{b}}$ \\
\hline 2.0 & 20 & $16.16^{\mathrm{a}}$ & $8.66^{\mathrm{b}}$ \\
& 30 & $22.60^{\mathrm{a}}$ & $10.78^{\mathrm{b}}$ \\
& $30.64^{\mathrm{a}}$ & $16.74^{\mathrm{b}}$ \\
\hline
\end{tabular}

Mean values in the same row bearing different superscripts are significantly different from each other $(P \leq 0.05)$.

$*$ Oxalic acid residue of treated chicken breast oven-roasted $\left(160^{\circ} \mathrm{C}\right.$ for $30 \mathrm{~min}$.) 
Table 2. Log-reduction of Listeria monocytogenes, Salmonella Enteritidis and E. coli O157:H7 inoculated onto chicken breast and treated with different concentrations of oxalic acid for 10, 20 and $30 \mathrm{~min}$.

\begin{tabular}{|c|c|c|c|c|}
\hline Oxalic acid con- & Dipping dura- & \multicolumn{3}{|c|}{ Log CFU/g } \\
\cline { 3 - 5 } centration (\%) & tion (min) & L. monocytogenes & S. Enteritidis & E. coli O157:H7 \\
\hline 0.0 & 10 & 0.51 & 0.05 & 0.17 \\
& 20 & 0.55 & 0.01 & 0.23 \\
& 30 & 0.48 & 0.06 & 0.16 \\
\hline 0.5 & 10 & 1.52 & 0.75 & 3.33 \\
& 20 & 1.81 & 0.90 & 3.32 \\
& 30 & 2.06 & 0.78 & 3.44 \\
\hline 1.0 & 10 & 1.55 & 0.84 & 3.66 \\
& 20 & 2.51 & 1.11 & 3.83 \\
& 30 & 2.31 & 1.37 & 3.9 \\
\hline 1.5 & 10 & 1.87 & 1.28 & 3.67 \\
& 20 & 2.57 & 1.41 & 3.86 \\
& 30 & 2.64 & 1.83 & 3.99 \\
\hline 2.0 & 10 & 2.49 & 1.32 & 3.68 \\
& 20 & 2.87 & 1.78 & 3.94 \\
& 30 & 2.67 & 2.02 & 4.12 \\
\hline
\end{tabular}

Table 3. Counts of Listeria monocytogenes $(\log \mathrm{CFU} / \mathrm{g})^{1,2}$ on chicken breasts treated with oxalic acid for 10,20 and 30 min and stored at $4^{\circ} \mathrm{C}$ for 14 days.

\begin{tabular}{|c|c|c|c|c|c|c|c|c|c|c|c|c|c|c|c|c|c|c|}
\hline \multirow{3}{*}{$\begin{array}{c}\text { Oxalic } \\
\text { acid } \\
\text { Conc. }(\%)\end{array}$} & \multicolumn{18}{|c|}{ Dipping time (min)/Storage time (day) } \\
\hline & \multicolumn{6}{|c|}{ 10-min dip } & \multicolumn{6}{|c|}{ 20-min dip } & \multicolumn{6}{|c|}{ 30-min dip } \\
\hline & 0 & 2 & 5 & 7 & 10 & 14 & 0 & 2 & 5 & 7 & 10 & 14 & 0 & 2 & 5 & 7 & 10 & 14 \\
\hline Control & $6.79^{\mathrm{a}}{ }_{\mathrm{A}}$ & $6.53_{\mathrm{A}}^{\mathrm{a}}$ & $7.43^{a}{ }_{A B}$ & $7.66^{a}{ }_{A}$ & $8.16^{a}{ }_{A}$ & $8.63_{\mathrm{A}}^{\mathrm{a}}$ & $6.74^{\mathrm{a}}$ & $6.55^{\mathrm{a}}$ & $7.54_{\mathrm{A}}^{\mathrm{a}}$ & $7.71_{\mathrm{A}}^{\mathrm{a}}$ & $8.28^{\mathrm{a}}{ }_{\mathrm{A}}$ & $8.64^{\mathrm{a}}$ & $6.97^{\mathrm{a}}$ & $6.92^{\mathrm{a}}{ }_{\mathrm{B}}$ & $7.20^{\mathrm{a}}$ & $7.71_{\mathrm{A}}^{\mathrm{a}}$ & $8.35_{\mathrm{A}}^{\mathrm{a}}$ & $8.64_{\mathrm{A}}^{\mathrm{a}}$ \\
\hline 0.5 & $5.93^{\mathrm{b}}{ }_{\mathrm{A}}$ & $5.66^{\mathrm{b}}{ }_{\mathrm{A}}$ & $6.59^{\mathrm{b}}{ }_{\mathrm{A}}$ & $6.71_{\mathrm{A}}^{\mathrm{b}}$ & $6.72^{\mathrm{b}}{ }_{\mathrm{A}}$ & $6.74_{A}^{b}$ & $5.61_{\mathrm{B}}^{\mathrm{b}}$ & $5.02^{\mathrm{b}}{ }_{\mathrm{B}}$ & $5.55^{\mathrm{b}}{ }_{\mathrm{B}}$ & $5.95^{\mathrm{b}}{ }_{\mathrm{A}}$ & $6.16^{\mathrm{b}}{ }_{\mathrm{B}}$ & $6.54_{\mathrm{B}}^{\mathrm{b}}$ & $5.39^{\mathrm{b}}{ }_{\mathrm{C}}$ & $4.87^{\mathrm{b}}{ }_{\mathrm{C}}$ & $5.49^{\mathrm{b}}{ }_{\mathrm{C}}$ & $5.55^{\mathrm{b}}{ }_{\mathrm{A}}$ & $6.35^{\mathrm{b}}{ }_{\mathrm{C}}$ & $6.68^{b}{ }_{A}$ \\
\hline 1.0 & $5.90^{\mathrm{b}}{ }_{\mathrm{A}}$ & $5.61^{\mathrm{b}}{ }_{\mathrm{A}}$ & $6.44^{c}{ }_{A}$ & $6.52^{\mathrm{b}}{ }_{\mathrm{A}}$ & $6.45^{\mathrm{c}}{ }_{\mathrm{A}}$ & $6.51^{c}{ }_{A}$ & $4.94_{B}^{c}$ & $4.82^{c}{ }_{B}$ & $5.38^{\mathrm{c}}{ }_{\mathrm{B}}$ & $5.47^{\mathrm{b}}{ }_{\mathrm{B}}$ & $6.03_{B}^{c}$ & $6.35^{\mathrm{c}}{ }_{\mathrm{B}}$ & $5.14^{c}{ }_{C}$ & $4.86^{\mathrm{b}}{ }_{\mathrm{B}}$ & $5.19^{c}{ }_{C}$ & $5.46^{\mathrm{b}}{ }_{\mathrm{B}}$ & $6.16^{\mathrm{c}}{ }_{\mathrm{C}}$ & $6.76_{\mathrm{A}}^{\mathrm{b}}$ \\
\hline 1.5 & $5.58^{c}{ }_{A}$ & $5.40^{\mathrm{c}}{ }_{\mathrm{A}}^{\mathrm{A}}$ & $5.68^{\mathrm{d}}{ }_{\mathrm{A}}$ & $5.81^{c}{ }_{A}$ & $5.83^{\mathrm{d}}{ }_{\mathrm{A}}$ & $6.08^{\mathrm{d}}{ }_{\mathrm{A}}$ & $4.88^{c}{ }_{B}^{c}$ & $4.91^{\mathrm{d}}{ }_{\mathrm{B}}$ & $4.71^{\mathrm{d}}{ }_{\mathrm{B}}$ & $5.38^{\mathrm{b}}{ }_{\mathrm{B}}$ & $4.95^{\mathrm{d}}{ }_{\mathrm{B}}$ & $5.12^{\mathrm{d}}{ }_{\mathrm{B}}$ & $4.81^{\mathrm{d}}{ }_{\mathrm{B}}$ & $4.33^{c}{ }_{C}$ & $4.62^{\mathrm{d}}{ }_{\mathrm{C}}$ & $4.66^{c}{ }_{C}$ & $4.67^{\mathrm{d}}{ }_{\mathrm{C}}$ & $5.35^{c}{ }_{C}$ \\
\hline 2.0 & $4.96^{\mathrm{d}}{ }_{\mathrm{A}}$ & $4.82^{\mathrm{d}}{ }_{\mathrm{A}}$ & $5.50^{e}{ }_{A}$ & $5.75^{\mathrm{c}}{ }_{\mathrm{A}}$ & $5.59^{\mathrm{e}}{ }_{\mathrm{A}}$ & $5.68^{e}{ }_{A}$ & $4.58^{\mathrm{d}}{ }_{\mathrm{B}}$ & $4.31^{\mathrm{e}}$ & $4.57^{\mathrm{d}}{ }_{\mathrm{B}}$ & $4.65^{\mathrm{c}}{ }_{\mathrm{B}}$ & $4.81^{\mathrm{e}}$ & $4.98_{B}^{e}$ & $4.78^{\mathrm{d}}{ }_{\mathrm{B}}$ & $4.21^{\mathrm{c}}$ & $4.40^{\mathrm{d}}{ }_{\mathrm{B}}$ & $4.61^{\mathrm{c}}{ }_{\mathrm{B}}$ & $4.61_{C}^{\mathrm{d}}$ & $4.75^{\mathrm{d}}{ }_{\mathrm{C}}$ \\
\hline
\end{tabular}

${ }^{1}$ Mean values in the same column bearing different superscripts are significantly different from each other $(P \leq 0.05)$.

${ }^{2}$ Mean values in the same row under same day bearing different subscripts are significantly different from each other $(P \leq 0.05)$

storage for 10-14 days. After day 14 of storage, Listeria counts on oxalic acid treated chicken breast were 1.9- 3.89 $\log \mathrm{CFU} / \mathrm{g}$ less than on control breasts. In addition, at the end of the 14 day storage Listeria monocytogenes counts on chicken breast treated with $2.0 \%$ oxalic acid for 20 or $30 \mathrm{~min}$ were less than $5 \log \mathrm{CFU} / \mathrm{g}$. The optimum concentration of oxalic acid and dipping time, for decontamination of Listeria monocytogenes, is the combination of $2 \%$ and $30 \mathrm{~min}$ of dipping. However, $1.5 \%$ oxalic acid at $30 \mathrm{~min}$ dipping time achieved similar results.

The effect of treating chicken breast with oxalic acid on counts of $S$. Enteritidis is shown in Table 4. Dipping chicken breast in oxalic acid solutions for 10, 20 or 30 min caused significant reductions in Salmonella counts. Additionally, dipping in $0.5-2.0 \%$ oxalic acid solution for 10, 20 or 30 min caused significant reductions in Salmonella counts during storage for 10 days, with the exception of $2 \%$ oxalic acid treated chicken breast on which Salmonella continued to decrease till the end of the 14 day storage. Counts of $S$. Enteritidis on chicken breasts treated with 1.0- 2.0\% oxalic acid for $30 \mathrm{~min}$ remained less than $6 \log \mathrm{CFU} / \mathrm{g}$ throughout the 14 days storage at $4{ }^{\circ} \mathrm{C}$ whilst Salmonella counts on $0.5 \%$ oxalic acid treated chicken breast for 10-30 min were higher than $6 \log \mathrm{CFU} / \mathrm{g}$. By the end of the 14 days storage, the chicken breast dipped in oxalic acid had significantly lower Salmonella counts than on the control samples. Also, the chicken breast dipped in $2 \%$ oxalic acid had less Salmonella counts than control samples at the end of storage. The optimum concentration of oxalic acid and dipping time, for decontamination of $S$. Enteritidis, is the combination of $2 \%$ and
30 min of dipping. However, $1.5 \%$ oxalic acid at 30 min dipping time achieved similar results.

With regard to E. coli $\mathrm{O} 157: \mathrm{H} 7$, treating chicken breast with oxalic acid for 10 to 30 min caused a significant reduction in E. coli O157:H7 counts and also retarded its growth during the 14 days of storage at $4^{\circ} \mathrm{C}$ (Table 5). However, E. coli O157:H7 counts on chicken breast dipped in water (control) continued to increase throughout the 14 days storage and reached a maximum of between 8.10 and $8.21 \mathrm{log} \mathrm{CFU} / \mathrm{g}$ at the end of storage. Dipping chicken breast in oxalic acid for 30 min resulted in significantly greater reductions in E. coli $\mathrm{O} 157: \mathrm{H} 7$ counts compared to 10 or 20 min dipping. E. coli $\mathrm{O} 157: \mathrm{H} 7$ counts on $1.5 \%$ oxalic acid treated chicken breast for $30 \mathrm{~min}$ and $2.0 \%$ oxalic acid treated chicken for 20 or $30 \mathrm{~min}$ remained less than $4 \mathrm{log} \mathrm{CFU} / \mathrm{g}$ throughout the 14 days storage. At the end of the 14 days storage, E. coli O157:H7 counts on oxalic acid treated chicken breast were 3.01$4.33 \log \mathrm{CFU} / \mathrm{g}$ less than counts on water treated chicken breasts which were above $\log 8.0 \mathrm{CFU} / \mathrm{g}$. Treating chicken with $2 \%$ oxalic acid seem to have the same effect on E. coli O157:H7 independent of time of dipping. From the results, the optimum concentration of oxalic acid and dipping time, for decontamination of E. coli $\mathrm{O} 157: \mathrm{H} 7$, is the combination of $2 \%$ at $20 \mathrm{~min}$. However, $1.5 \%$ oxalic acid at 20 min dipping time seem to achieve similar results.

There are several published reports on the use of organic acids such as lactic acid for reducing the microbial counts in poultry, meat and in swine [16, 28-30]. Reduction in Listeria monocytogenes 
Table 4. Counts of Salmonella Enteritidis $(\log \mathrm{CFU} / \mathrm{g})^{1,2}$ on chicken breasts treated with oxalic acid for 10, 20 and 30 min and stored at $4^{\circ} \mathrm{C}$ for 14 days.

\begin{tabular}{|c|c|c|c|c|c|c|c|c|c|c|c|c|c|c|c|c|c|c|}
\hline \multirow{3}{*}{$\begin{array}{c}\text { Oxalic } \\
\text { acid } \\
\text { Conc. ( } \%)\end{array}$} & \multicolumn{18}{|c|}{ Dipping time (min)/Storage time (day) } \\
\hline & \multicolumn{6}{|c|}{ 10-min dip } & \multicolumn{6}{|c|}{ 20-min dip } & \multicolumn{6}{|c|}{ 30-min dip } \\
\hline & 0 & 2 & 5 & 7 & 10 & 14 & 0 & 2 & 5 & 7 & 10 & 14 & 0 & 2 & 5 & 7 & 10 & 14 \\
\hline Control & $7.31^{2}{ }_{A}$ & $7.33_{\mathrm{A}}^{\mathrm{a}}$ & $7.54^{a}{ }_{A}$ & $7.24^{\mathrm{a}}$ & $7.42^{a}{ }_{A}$ & $8.28^{\mathrm{a}}{ }_{A}$ & $7.35_{B}^{\mathrm{a}}$ & $7.02^{\mathrm{a}}$ & $7.21_{\mathrm{B}}^{\mathrm{a}}$ & $7.27^{\mathrm{a}}{ }_{\mathrm{A}}$ & $7.28^{\mathrm{a}}{ }_{\mathrm{B}}$ & $8.23^{\mathrm{a}}{ }_{\mathrm{A}}$ & $7.30^{\mathrm{a}}{ }_{\mathrm{B}}$ & $7.34_{\mathrm{A}}^{a}$ & $7.27^{\mathrm{a}}{ }_{\mathrm{B}}$ & $7.23^{\mathrm{a}}{ }_{\mathrm{A}}$ & $7.76_{A}^{a}$ & $8.15^{\mathrm{a}}$ \\
\hline 0.5 & $6.61^{\mathrm{b}}{ }_{\mathrm{A}}$ & $6.66^{\mathrm{b}}$ & $6.82^{\mathrm{b}}{ }_{\mathrm{A}}$ & $6.44_{\mathrm{A}}^{\mathrm{b}}$ & $6.41^{\mathrm{b}}{ }_{\mathrm{A}}$ & $6.59^{\mathrm{b}}{ }_{\mathrm{A}}$ & $6.46^{\mathrm{b}}{ }_{\mathrm{B}}$ & $6.54^{\mathrm{b}}$ & $6.37^{\mathrm{b}}{ }_{\mathrm{B}}$ & $6.03^{\mathrm{b}}$ & $6.28^{\mathrm{b}}{ }_{\mathrm{B}}$ & $6.39^{\mathrm{b}}{ }_{\mathrm{B}}$ & $6.58^{\mathrm{b}}{ }_{\mathrm{A}}$ & $6.14_{C}^{\mathrm{b}}$ & $6.33_{\mathrm{B}}^{\mathrm{b}}$ & $6.50^{\mathrm{b}}{ }_{\mathrm{A}}$ & $6.65^{\mathrm{b}}{ }_{\mathrm{C}}$ & $6.79^{\mathrm{b}}$ \\
\hline 1 & $6.52^{\mathrm{b}}$ & $5.96^{c}$ & $5.82^{\mathrm{c}}$ & $5.90^{c}$ & $6.02^{\mathrm{c}}$ & $6.21^{\mathrm{c}}$ & $6.25^{\mathrm{c}}{ }_{\mathrm{B}}$ & $6.27^{c}{ }_{B}$ & $5.84^{c}$ & $5.77^{\mathrm{c}}{ }_{\mathrm{B}}$ & $5.87^{\mathrm{c}}{ }_{\mathrm{AB}}$ & $5.93^{\mathrm{c}}{ }_{\mathrm{B}}$ & $5.99^{c}{ }_{C}$ & $5.41_{G}^{\mathrm{c}}$ & $5.63^{c}$ & $5.47^{\mathrm{c}}{ }_{\mathrm{C}}$ & $5.86^{\mathrm{c}}{ }_{\mathrm{B}}$ & $5.82^{\mathrm{c}}$ \\
\hline 1.5 & $6.08^{\mathrm{c}}{ }_{\mathrm{A}}$ & $5.88^{c}$ & $5.50^{\mathrm{d}}$ & $5.70^{\mathrm{d}}$ & $5.80^{\mathrm{d}}$ & $6.02^{\mathrm{d}}$ & $5.95^{\mathrm{d}}$ & $5.83^{\mathrm{d}}$ & $5.54^{\mathrm{d}}$ & $5.38^{\mathrm{d}}{ }_{\mathrm{B}}$ & $5.30^{\mathrm{d}}{ }_{\mathrm{B}}$ & $5.38_{\mathrm{B}}^{\mathrm{d}}$ & $5.53^{\mathrm{d}}{ }_{C}$ & $5.23^{\mathrm{d}}$ & $5.27^{\mathrm{d}}$ & $5.10_{\mathrm{B}}^{\mathrm{d}}$ & $4.44^{\mathrm{d}}{ }_{C}$ & $4.09^{\mathrm{d}}$ \\
\hline 2 & $6.04^{c}$ & $5.60^{\mathrm{d}}$ & $5.67^{\mathrm{e}}$ & $5.62^{\mathrm{d}}$ & $5.42^{\mathrm{e}}$ & $5.46^{\mathrm{e}}$ & $5.58^{\mathrm{e}}$ & $5.65^{\mathrm{e}}$ & $5.57^{\mathrm{d}}{ }_{\mathrm{B}}$ & $5.29^{\mathrm{d}}{ }_{\mathrm{B}}$ & $5.52^{\mathrm{e}}{ }_{\mathrm{B}}$ & $5.54^{\mathrm{e}}$ & $5.34^{e}{ }_{B}$ & $5.27^{\mathrm{cd}}$ & $4.42^{\mathrm{e}}{ }_{\mathrm{C}}$ & $4.31^{\mathrm{e}}{ }_{\mathrm{C}}$ & $4.50^{\mathrm{d}}{ }_{C}$ & $4.29^{\mathrm{e}}$ \\
\hline
\end{tabular}

${ }^{1}$ Mean values in the same column bearing different superscripts are significantly different from each other $(P \leq 0.05)$

${ }^{2}$ Mean values in the same row under same day bearing different subscripts are significantly different from each other $(P \leq 0.05)$

Table 5. Counts of E. coli $\mathrm{O} 157: \mathrm{H} 7(\log \mathrm{CFU} / \mathrm{g})^{1,2}$ on chicken breasts treated with oxalic acid for 10, 20 and $30 \mathrm{~min}$ and stored at $4^{\circ} \mathrm{C}$ for 14 days.

\begin{tabular}{|c|c|c|c|c|c|c|c|c|c|c|c|c|c|c|c|c|c|c|}
\hline \multirow{3}{*}{$\begin{array}{c}\text { Oxalic } \\
\text { acid } \\
\text { Conc. }(\%)\end{array}$} & \multicolumn{18}{|c|}{ Dipping time (min)/Storage time (day) } \\
\hline & \multicolumn{6}{|c|}{ 10-min dip } & \multicolumn{6}{|c|}{ 20-min dip } & \multicolumn{6}{|c|}{ 30-min dip } \\
\hline & 0 & 2 & 5 & 7 & 10 & 14 & 0 & 2 & 5 & 7 & 10 & 14 & 0 & 2 & 5 & 7 & 10 & 14 \\
\hline Control & $7.23^{\mathrm{a}}$ & $7.43^{\mathrm{a}}$ & $7.41^{2}$ & $7.59^{\mathrm{a}}$ & $7.87^{\mathrm{a}}$ & $8.15^{\mathrm{a}}$ & $7.17^{\mathrm{a}}$ & $7.39^{\mathrm{a}}$ & $7.45^{\mathrm{a}}$ & $7.53^{\mathrm{a}}$ & $7.75^{\mathrm{a}}$ & $8.21_{\mathrm{B}}^{\mathrm{a}}$ & $7.34_{B}^{\mathrm{a}}$ & $7.44^{\mathrm{a}}$ & $7.53^{\mathrm{a}}$ & $7.68^{\mathrm{a}}$ & $7.83^{\mathrm{a}}$ & $8.10^{\mathrm{a}}$ \\
\hline 1 & $3.74^{c}$ & $3.85^{\mathrm{c}}$ & $4.52^{\mathrm{b}}$ & $4.51^{\mathrm{c}}$ & $4.57^{\mathrm{c}}$ & $4.81^{\mathrm{c}}$ & $3.57^{\mathrm{c}}$ & $3.18^{\mathrm{c}}{ }_{\mathrm{B}}$ & $4.52^{\mathrm{b}}$ & $4.43^{\mathrm{c}}$ & $4.50^{c}$ & $4.59^{c}$ & $3.50_{\mathrm{B}}^{\mathrm{c}}$ & $3.29^{c}{ }_{B}$ & $3.74^{c}{ }_{B}$ & $4.21_{\mathrm{B}}^{\mathrm{c}}$ & $4.51^{\mathrm{c}}$ & $4.52^{\mathrm{c}}$ \\
\hline 1.5 & $3.73^{\mathrm{c}}$ & $3.70^{\mathrm{d}}$ & $3.68^{c}$ & $3.72^{\mathrm{d}}$ & $4.07^{\mathrm{d}}$ & $4.29^{\mathrm{d}}$ & $3.54^{c}{ }_{B}$ & $3.69^{\mathrm{d}}$ & $3.81^{\mathrm{c}}$ & $3.70^{\mathrm{d}}$ & $3.89^{\mathrm{d}}{ }_{\mathrm{B}}$ & $4.10^{\mathrm{d}}$ & $3.41^{\mathrm{d}}{ }_{\mathrm{B}}$ & $3.23_{\mathrm{B}}^{\mathrm{cd}}$ & $3.56^{\mathrm{d}}$ & $3.61^{\mathrm{d}}{ }_{\mathrm{B}}$ & $3.76^{\mathrm{d}}{ }_{\mathrm{B}}$ & $3.94^{\mathrm{d}}$ \\
\hline 2 & $3.72^{c}$ & $3.73^{\mathrm{e}}$ & $3.53^{\mathrm{c}}$ & $3.54^{\mathrm{e}}$ & $3.78^{\mathrm{e}}$ & $4.06^{\mathrm{e}}{ }_{\mathrm{A}}$ & $3.46_{\mathrm{B}}^{\mathrm{c}}$ & $3.80^{\mathrm{d}}{ }_{\mathrm{A}}$ & $3.46_{\mathrm{A}}^{\mathrm{d}}$ & $3.32^{\mathrm{e}}{ }_{\mathrm{B}}$ & $3.43_{\mathrm{B}}^{\mathrm{e}}$ & $3.57^{\mathrm{e}}{ }_{\mathrm{B}}$ & $3.28^{\mathrm{e}}{ }_{C}$ & $3.04^{\mathrm{d}}{ }_{\mathrm{B}}$ & $3.38_{\mathrm{A}}^{\mathrm{e}}$ & $3.13^{\mathrm{e}}{ }_{\mathrm{C}}$ & $3.35^{\mathrm{e}}{ }_{\mathrm{B}}$ & $3.77^{\mathrm{d}}{ }_{\mathrm{AF}}$ \\
\hline
\end{tabular}

${ }^{1}$ Mean values in the same column bearing different superscripts are significantly different from each other $(P \leq 0.05)$.

${ }^{2}$ Mean values in the same row under same day bearing different subscripts are significantly different from each other $(P \leq 0.05)$.

counts on oxalic acid treated chicken breast was relatively similar to earlier reports by Anang et al. [16] and Gonçalves, et al. [31] in chicken breast treated with up to $4 \%$ lactic acid. The authors had reported a $2.83 \log \mathrm{CFU}$ and $2.96 \log \mathrm{CFU}$ reductions, respectively, in Listeria monocytogenes whilst in the present study a reduction of $2.87 \log$ CFU was observed when chicken breast was dipped in $2 \%$ oxalic acid at $25^{\circ} \mathrm{C}$ for $20 \mathrm{~min}$. Greer and Dilts [17]treated pork lean tissue with $3 \%$ lactic acid and observed 1-log reduction in L. monocytogenes counts. Furthermore results from their study, after storage for 7 days, a maximum of $2 \mathrm{log}$ reduction in Listeria counts was observed when pork lean tissue was treated with $3 \%$ lactic acid at $55^{\circ} \mathrm{C}$. In another study, Özdemir et al. [30] reported a 0.69 and $1.09 \mathrm{log}$ reduction in L. monocytogenes counts in beef treated with 1 and $2 \%$ lactic acid, respectively. These reductions in Listeria counts were relatively lower than those reported in the present study, which were 1.55 and $2.49 \log$ CFU/g (1 and 2\% oxalic acid). Further from their study, after 5 days of storage (at $4^{\circ} \mathrm{C}$ ) reductions in Listeria counts (by 2.16 and $2.54 \mathrm{log}$, respectively) were also observed. Whereas in this study, after 5 days of storage, the log reduction in Listeria count was at a maximum of 2.26 and $3.05 \log$ at 1 and $2 \%$ levels of oxalic acid, respectively. Additionally, organic acids such as acetic acid have also been indicated to be effective against Listeria monocytogenes inoculated in beef $[10,29,32]$.

Results of the present study indicate that oxalic acid is more effective in killing and inhibiting $S$. Enteritidis and E. coli compared to lactic and acetic acid. Beef inoculated with $S$. Typhimurium treated with $2 \%$ acetic acid, showed a $\log$ reduction of 1 unit [33]. Podolak et al. [34] also reported a log reduction of 0.2-0.8 units in Salmonella counts when beef was treated with $1 \%$ lactic or acetic acid at $55^{\circ} \mathrm{C}$. Anang et al. [16] observed just above one log reduction in $S$. Enteritidis counts when chicken breast was treated with $0.5-2 \%$ lactic acid. Treating chicken breast with oxalic acid, on the other hand, led to initial reduction of $S$. Enteritidis inoculated onto chicken breast by 2.02 logs. Oxalic acid also showed residual effect throughout the storage period under study. These results show the additional benefit obtained when oxalic acid was used to decontaminate the pathogen.

Salmonella spp. was found as more sensitive to organic acid decontamination than E. coli O157:H7 [16, 35]. Dubal et al. [36] observed a complete inhibition of $S$. Typhymurium whereas $E$. coli count was reduced by $0.42 \log$ units when inoculated sheep (goat) meat was exposed to $2 \%$ lactic acid. However, results from the present study indicate that E. coli O157:H7 is more sensitive to oxalic acid than $S$. Enteritidis. When chicken breast was dipped in oxalic acid, the maximum log reduction in Salmonella counts was 2.02 whilst the maximum log reduction in E. coli count was more than doubled, at a value of 4.12. Counts of $S$. Typhimurium DT104 and non-O157:H7 enterohaemorrahgic E. coli inoculated onto beef surface were equally reduced in the range of 2-3 log $\mathrm{CFU} / \mathrm{cm}^{2}$ after treating with lactic or acetic acid spray [37]. The difference in the effect of oxalic acid against Salmonella Enteritidis and E. coli $\mathrm{O} 157: \mathrm{H} 7$ in the present study will, however, needs further evaluation.

Results from the present study clearly demonstrated that treating chicken breast with oxalic acid could be beneficial in the decontamination of poultry contaminated by certain common foodborne pathogens. The results also indicate the possible delay in growth or inhibition of the pathogens during subsequent storage at $4^{\circ} \mathrm{C}$. Further commercial application of oxalic acid as a preservative is warranted.

\section{Acknowledgments}

This study was supported through a grant from Malaysian Ministry of Science Technology and Environment through the Science Fund Mechanism.

\section{References}

[1]. Klinger I (2000) Foodborne human pathogens and their toxic metabolites in Israel. Microbial food contamination. CRC press, Washington D.C. 1-4.

[2]. Callaway TR, Edrington TS, Anderson RC, Byrd JA, Nisbet DJ (2008) Gas- 
trointestinal microbial ecology and the safety of our food supply as related to Salmonella. J Anim Sci 86(14 Suppl): E163-E172.

[3]. Mulder RW (1999) Hygiene during transport, slaughter and processing. In Poultry Meat Science. Poultry Science Symposium Series 25: 277-285.

[4]. Kotula KL, Pandya Y (1995) Bacterial contamination of broiler chicken before scalding. J Food Prot 58(12): 1326-1329.

[5]. Alonso-Hernando A, Alonso-Calleja C, Capita R (2010) Effects of exposure to poultry chemical decontaminants on the membrane fluidity of Listeria monocytogenes and Salmonella enterica strains. Int J Food Microbiol 137(23): $130-136$.

[6]. Rantsiou K, Lamberti C, Cocolin L (2010) Survey of Campylobacter jejuni in retail chicken meat products by application of a quantitative PCR protocol. Int J Food Microbiol 141(Suppl 1): S75-S79.

[7]. Bystroń J, Podkowik M, Piasecki T, Wieliczko A, Molenda J, et al. (2010) Genotypes and enterotoxin gene content of $S$. aureus isolates from poultry. Vet Microbiol 144(3-4): 498-501.

[8]. Mataragas M, Skandamis PN, Drosinos EH (2008) Risk profiles of pork and poultry meat and risk ratings of various pathogen/product combinations. Int J Food Microbiol 126(1-2): 1-12.

[9]. del Río E, González de Caso B, Prieto M, Alonso-Calleja C, Capita R (2008) Effect of poultry decontaminants concentration on growth kinetics for pathogenic and spoilage bacteria. Food Microbiol 25(7): 888-894.

[10]. Loretz M, Stephan R, Zweifel C (2010) Antimicrobial activity of decontamination treatments for poultry carcasses: A literature survey. Food Control 21(6): 791-804.

[11]. Mani-López E, García HS, López-Malo A (2012) Organic acids as antimicrobials to control Salmonella in meat and poultry products. Food Res Int 45(2): 713-721.

[12]. Huang H, Jing G, Guo L, Zhang D, Yang B, et al. (2013) Effect of oxalic acid on ripening attributes of banana fruit during storage. Postharvest Biol Technol 84: 22-27.

[13]. Kayashima T, Katayama T (2002) Oxalic acid is available as a natural antioxidant in some systems. Biochim Biophys Acta 1573(1): 1-3.

[14]. Yoruk R, Balaban MO, Marshall MR, Yoruk S (2002) The inhibitory effect of oxalic acid on browning of banana slices (30G-18). In Annual Meeting and Food Expo, Anaheim, California. 18-30.

[15]. Anang DM, Rusul G, Son R, Bakar J, Beuchat LR (2006) Inhibitory effect of oxalic acid on bacterial spoilage of raw chilled chicken. J Food Prot 69(8): 1913-1919.

[16]. Anang DM, Rusul G, Bakar J, Ling FH (2007) Effects of lactic acid and lauricidin on the survival of Listeria monocytogenes, Salmonella Enteritidis and Escherichia coli O157:H7 in chicken breast stored at $4{ }^{\circ} \mathrm{C}$. Food Cont 18(8): 961-969.

[17]. Greer GG, Dilts BD (1995) Lactic acid inhibition of the growth of spoilage bacteria and cold tolerant pathogens on pork. Int J Food Microbiol 25(2): 141-151.

[18]. Van Netten P, Perales J, Van De Moosdijk A, Curtis GD, Mossel DA (1989) Liquid and solid selective differential media for the detection and enumeration of Listeria monocytogenes and other Listeria spp. Int J Food Microbiol 8(4): 299-316.

[19]. Savage GP, Vanhanen L, Mason SM, Ross AB (2000) Effect of cooking on the soluble and insoluble oxalate content of some New Zealand foods. J Food Comp Anal 13(3): 201-206.

[20]. United States Department of Agriculture (USDA) (2009) Agricultural Handbook. No. 8-11, Vegetables and Vegetables Products. http://www.ars. usda.gov/Services/docs.htm? docid=9444.

[21]. Anonymous (2005) Rhubarb Compendium. http://www.rhubarbinfo.com/ rhubarb-poison.html.

[22]. Blackburn CW, McCarthy JD (2000) Modifications to methods for the enumeration and detection of injured Escherichia coli O157:H7 in foods. Int J Food Microbiol 55(1-3): 285-290.

[23]. Clavero MRS, Beuchat LR (1995) Suitability of selective plating media for recovering heat- or freeze-stressed Escherichia coli 0157:H7 from tryptic soy broth and ground beef. Appl Environ Microbiol 61(9): 3268-3273.

[24]. Sage JR, Ingham SC (1998) Evaluating survival of Escherichia coli 0157:H7 in frozen and thawed apple cider: potential use of a hydrophobic grid membrane filter-SD-39 agar method. J Food Prot 61(4): 490-494.

[25]. Singh N, Singh RK, Bhunia AK (2003) Sequential disinfection of Escherichia coli O157:H7 inoculated alfalfa seeds before and during sprouting using aqueous chlorine dioxide, ozonated water, and thyme essential oil. LWTFood Sci Technol 36(2): 235-243.

[26]. Blagojevic B, Antic D, Adzic B, Tasic T, Ikonic P, et al. (2015) Decontamination of incoming beef trimmings with hot lactic acid solution to improve microbial safety of resulting dry fermented sausages: A pilot study. Food Cont 54: 144-149.

[27]. Lang MM, Ingham BH, Ingham SC (2000) Efficacy of novel organic acid and hypochlorite treatments for eliminating Escherichia coli O157:H7 from alfalfa seeds prior to sprouting. Int J Food Microbiol 58(1-2): 73-82.

[28]. Anang DM, Rusul G, Ling FH, Bhat R (2010) Inhibitory effects of lactic acid and lauricidin on spoilage organisms of chicken breast during storage at chilled temperature. Int J Food Microbiol 144(1): 152-159.

[29]. Ikeda JS, Samelis J, Kendall PA, Smith GC, Sofos JN (2003) Acid adaptation does not promote survival or growth of Listeria monocytogenes on fresh beef following acid and nonacid decontamination treatments. J Food Prot 66(6): 985-992.

[30]. Özdemir H, Yildirim Y, Küplülü Ö, Koluman A, Göncüoğlu M, et al. (2006) Effects of lactic acid and hot water treatments on Salmonella Typhimurium and Listeria monocytogenes on beef. Food Cont 17(4): 299-303.

[31]. Gonçalves AC, Almeida RCC, Alves MAO, Almeida PF (2005) Quantitative investigation on the effects of chemical treatments in reducing Listeria monocytogenes populations on chicken breast meat. Food Cont 16(7): 617622.

[32]. Conner DE, Kotrola JS, Mikel WB, Tamplyn KC (1997) Effect of aceticlactic acid treatments applied to beef trim on populations of Escherichia coli O157:H7 and Listeria monocytogenes in ground beef. J Food Prot 60(12): 1560-1563.

[33]. Tinney KS, Miller MF, Ramsey CB, Thompson LD, Carr MA (1997) Reduction of microorganisms on beef carcasses with electricity and acetic acid. J Food Prot 60(6): 625-628.

[34]. Podolak R, Zayas J, Kastner CL, Fung DYC (1995) Reduction of Listeria monocytogenes, Escherichia coli O157:H7 and Salmonella Typhimurium during storage of beef sanitized with fumaric, acetic and lactic acids. J Food Saf 15(3): 283-290.

[35]. Hardin MD, Acuff GR, Lucia LM, Oman JS, Savell JW (1995) Comparison of methods for decontamination from beef carcass surfaces. J Food Prot 58(4): 368-374.

[36]. Dubal ZB, Paturkar AM, Waskar VS, Zende RJ, Latha C, et al. (2004) Effect of food grade organic acids on inoculated S. aureus, L. monocytogenes, E. coli and S. Typhimurium in sheep/goat meat stored at refrigerated temperature. Meat Sci 66(4): 817-821.

[37]. Cutter CN, Rivera-Betancourt M (2000) Interventions for the reduction of Salmonella Typhimurium DT104 and non-O157:H7 enterohaemorrahgic E. coli on beef surfaces. J Food Prot 63(10): 1326-1332. 